\title{
Adult T-Cell Leukemia/Lymphoma
}

National Cancer Institute

\section{Source}

National Cancer Institute. Adult T-Cell Leukemia/Lymphoma. NCI Thesaurus. Code C3184.

A peripheral (mature) T-cell neoplasm linked to the human T-cell leukemia virus type 1 (HTLV-1). Adult T-cell leukemia/lymphoma is endemic in several regions of the world, in particular Japan, the Caribbean, and parts of Central Africa. 